\title{
European Security Architecture after the United Kingdom's Withdrawal from the European Union: Future Scenarios
}

The European security architecture inherited from the period of the Cold War encompasses a few most important international organisations - first of all, NATO, EU and OSCE, members of which are most European countries - and institutional rules as well as numerous informal patterns of state behaviour and status. 2019 is to see the withdrawal of the United Kingdom from the European Union, which is one of the key institutional "axes" of the European security architecture. This will potentially have an impact on the future of the entire organisation, hence - on the security on the old continent. This article aims at compiling a set of alternative scenarios of the evolution of the European security through the use of the scenario building technique which is still bizarre in political science. To this end, interaction of four "driving forces", namely, 1) USA involvement, 2) threats of regional scope, 3) leadership of Germany (and France) in the promotion of the European integration, and 4) stability of the UK government, in the next seven years, is analysed. Various combinations of these variables lead to the crystallisation of three alternative plots of scenarios: 1) closer European security and defence union, 2) new Cold War, and 3) revival of the global "Anglosphere". Still, as seen from the practice of application of the scenario building technique, in the medium term, a parallel and only partial materialisation of all three scenarios is most likely.

\section{Introduction}

The number of academic publications on the subject of European "security architecture" or "security order" increased dramatically in 1990s and 2000s, given the end of the Cold War, the transformation of the European Economic Community into a political union with a common foreign and security policy and the local conflicts that emerged in the periphery of the European continent (Balkans and Caucasus, in particular). Most of publications of this area focus on the development of the main international organisations in the region -

\footnotetext{
* Dr. Vytautas Isoda is an Assoc. Professor at the Department of Political Science of the General Jonas Žemaitis Military Academy of Lithuania. Correspondence address: Šilo 5A, LT-10322 Vilnius, Lithuania, phone: +370 5210 3569, e-mail: vytautas.isoda@lka.lt
}

DOI: 10.2478/lasr-2019-0007 
NATO, EU, OSCE - and on institutional changes of and interaction between these organisations (competition and cooperation) ${ }^{1}$. Although the notion of "security architecture" in academic literature is used fairly freely and has no strict definition, according to William Tow and Brendan Taylor, it is usually defined as "an overarching, coherent and comprehensive security structure for a geographically-defined area, which facilitates the resolution of that region's policy concerns and achieves its security objectives" ${ }^{2}$. In other words, regional security architecture encompasses both formal institutional rules typical to the international organisations of the region and the patterns of status and behaviour of the security objects themselves (first and foremost, member states of these organisations) which sometimes reach beyond formal regulations.

Among the European countries participating in the key regional security organisations and creating the European security architecture political scientists usually single out the most important centres of power which determine the dynamics of regional security. A specific role in this architecture as to the "geopolitical bridge" connecting the USA and the biggest countries of the continental Europe is often attributed to the United Kingdom ${ }^{3}$. For this particular reason the official address by London dated 29 March 2017 to the European Council regarding termination of UK's membership in this organisation and the formal negotiation over withdrawal which started in June the same year may potentially have considerable consequences on the European security architecture. Great Britain was one of the two (alongside France) initiators of the single EU security and defence policy in 1998-1999 and actively moderated the conclusion of Berlin Plus agreement between NATO and the EU in 2002-2003; it is also one of the countries which deploys the highest number of its troops in Europe (among them, around 1,200 servicemen in the EU Member States Estonia, Poland and Cyprus, as part of NATO "enhanced forward presence"

\footnotetext{
${ }^{1}$ For example, see: Anderson, S. (1995), "EU, NATO, and CSCE Responses to the Yugoslav Crisis: Testing Europe's New Security Architecture”, European Security, Vol. 4 (No. 2), p. 328-353; Sperling, J. (1999), Two Tiers or Two Speeds?: The European Security Order and the Enlargement of the European Union and NATO, Manchester, New York: Manchester University Press; Hauser G., Kernic, F. (2006), European Security in Transition, London, New York: Routledge; Hoffman, S. (2011), "Why Institutional Overlap Matters: CSDP in the European Security Architecture", Journal of Common Market Studies, Vol. 49 (No. 1), p. 101-120. ${ }^{2}$ Tow, W. T., Taylor, B. (2010), “What is Asian Security Architecture?", Review of International Studies, Vol. 36 (No. 1), p. 96.

${ }^{3}$ For example, see: Howorth, J. (2005), "The Euro-Atlantic Security Dilemma: France, Britain, and the ESDP”, Journal of Transatlantic Studies, Vol. 3 (No. 1), p. 39-54; Stokes, D., Whitman, R. G. (2013), "Transatlantic Triage? European and UK 'Grand Strategy' after the US Rebalance to Asia”, International Affairs, Vol. 89 (No. 5), p. 1087-1107.

${ }^{4}$ NATO's Enhanced Forward Presence Fact sheet, February 2018. Available at: www.nato.int/factsheets [accessed on 01-06-2018].
} 
and part of the UN mission UNFICYP ${ }^{5}$, as well as about 140 seamen in the EU naval operations Sophia and Atalanta ${ }^{6}$, of which the latter's headquarters were initially established in the $\mathrm{UK}^{7}$ ). Although formally the withdrawal of the UK from the EU should not affects its obligations to NATO or OSCE, competition over power and disputes over the international rights and duties of the country in relation to the previous membership in the EU will undoubtedly change regional security dynamics.

The purpose of this article is to construct a few possible scenarios of the change in European security architecture in the medium term ( 7 years) counting from the start of the official negotiations over withdrawal (2017). Although at the time this article was being written the so-called Brexit ${ }^{8}$ negotiation was mid-way to the completion, all procedures took place mostly behind closed doors and based on the principle "unless agreement is reached on everything, no agreement has been reached", thus making the final content of the withdrawal agreement and even the deadline unclear. Although Article 50 of the Treaty on European Union obligates the parties to the negotiation to ratify the withdrawal agreement within a period of two years from the date Article 50 is activated, i.e. from the date of notification of the intention to withdraw. It cannot be excluded that in case of failure to reach an agreement before 29 March 2019, EU 27 and the UK would extend the aforementioned deadline by mutual agreement. The prospect of the so-called "No-Deal Brexit" cannot be excluded either. In fact, the result of the negotiation and the conditions of Britain leaving the EU are not considered the main factor of the change in the European security architecture (as one of the "driving forces" of scenarios) in this article. The Brexit process is rather treated as the reference point of the scenarios constructed here. The short-term scenarios built by political scientists (1 to 3 years) are usually more "accurate" than medium-term (4 to 10 years) and long-term (>10 years) scenarios, however, the last two have higher analytical value since they enable the political scientists to dissociate the scenarios from the present-day assumptions about the world and to avoid the "imprisonment" of the future in the present.

There are not many studies on the subject of Brexit (at least in the outlets of the prevailing Western academic publishers and research institutions), since

\footnotetext{
${ }^{5}$ UNFICYP Fact Sheet, April 2018. Available at: https://peacekeeping.un.org/en/mission/unficyp [accessed on 01-06-2018].

${ }^{6}$ EU's Global Engagement: A Database of the EU CSDP Military Operations and Civilian Missions Worldwide, 2003-2017. Codebook Version 2.0. European University Institute. Available at: http://globalgovernanceprogramme.eui.eu/eu-global-engagement-database/ [accessed on 01-06-2018].

${ }^{7}$ However, with UK withdrawal from the EU under way, the operational headquarters of EUNAVFOR

"Atalanta" was moved from Northwood, England to Rota naval base in Southern Spain.

${ }^{8}$ The term "Brexit" is a neologism coined by the British media and derives from "British exit".
} 
more significant outcomes of the UK's withdrawal from the EU will most likely become visible only after the completion of the procedure. Actually, after the government of the former Prime Minister David Cameron announced the referendum on the UK's withdrawal from the EU in June 2016, researchers tried to build various future "scenarios" of the aftermath of this referendum. For instance, Tim Oliver and Michael Williams presented three scenarios of the EU-USA relationship after the Brexit referendum which they called the Good, the Bad and the Ugly. Another British scholar Richard Whitman drew two alternative pictures of the British foreign and security policy given the results of the future referendum (Brexit and Bremain scenarios) ${ }^{10}$. Yet, the causal factor (or speaking the language of the scenario builders - the "driving force") in these thought experiments was the decision of the British nation on the membership of the UK in the EU which is now known (in the referendum of 23 June 2016, about $52 \%$ of the British population voted in favour of UK's withdrawal from the European Union). This means that today future scenarios should be constructed based on different driving forces.

In numerous publications which emerged after the 2016 referendum ${ }^{11}$ the focus was first put on the explanation of the referendum results. Only a handful of authors attempted to forecast the consequences of the UK's withdrawal from the EU. For instance, Karen E. Smith and Megan Dee in their article examine the comparative "weight" of Great Britain and its opportunities to act in different formats of the United Nations in which it was previously forced to stick to the general EU position ${ }^{12}$. Political scientists of the University of Birmingham Mark Webber and David Dunn gave pessimistic forecasts of NATO's future and UK's role in the Alliance in case the UK left the EU (primarily because of potential decrease in national defence spending and ambiguity regarding the collective Euro-Atlantic identity $)^{13}$. An academic study which came closest to applying the scenario building methodology was put forth by the sociologist Simon Susen in his article "No Exit from Brexit?". He lists six scenarios of the course of negotiation over the UK's withdrawal from the EU as follows: "Straight Hard Brexit", "Straight Soft Brexit", "Relegitimized Hard Brexit", "Relegitimized Soft Brexit", "Autocratic

\footnotetext{
${ }^{9}$ Oliver, T., Williams, M. (2016), "Special Relationships in Flux: Brexit and the Future of the US-EU and US-UK Relationships", International Affairs, Vol. 92 (No. 3), p. 565-567.

${ }^{10}$ Whitman, R. G. (2016), "Brexit or Bremain: What Future for the UK's European Diplomatic Strategy?", International Affairs, Vol. 92 (No. 3), p. 520-524.

${ }^{11}$ E.g., Special Issue of The British Journal of Politics and International Relations, Vol. 19 (No. 3); Outhwaite W. (2017), Brexit: Sociological Responses, London, New York: Anthem Press.

${ }^{12}$ Smith, K. E., Dee, M. (2017), "UK Diplomacy at the UN after Brexit: Challenges and Opportunities", The British Journal of Politics and International Relations, Vol. 19 (No. 3), p. 527-542.

${ }^{13}$ Webber, M., Dunn, D. (2017), “The UK, the European Union and NATO: Brexit's Unintended Consequences", Global Affairs, Vol. 2 (No. 5), p. 527-542.
} 
No Brexit", and "Legitimized No Brexit"14. Still the set of scenarios designed by this author is not based on any specific combinations of the "driving forces", and encompass only the modelling of the future UK-EU relationship and (implicitly) only the short-term relationship. The object of the set of scenarios proposed in this article is a holistic "image" of the European security architecture (in which the UK-EU, UK-NATO or NATO-EU relations are important but partial objects only) and the driving forces of the scenarios are "derived" from the prevailing theoretical traditions in International Relations. From this point of view, this article is a modest advancement in the scholarly research on Brexit and European security.

\section{Scenario Building Methodology in Political Science}

In the history of political science (which is almost one hundred years old), causal empirical research and building of causal theories have become a methodological orthodoxy. To meet the scholarly standards, a study into the "causes" of any political phenomenon has to "adhere to a set of rules of inference on which its validity depends" 15 . Such rules are usually summarized by the umbrella term "methodology". To evaluate the causes behind any observable phenomenon, i.e. to identify an independent variable that came before the phenomenon in question, usually the latter has to reach the state "worth of explanation"; in other words, it has to be a phenomena of the present or the past. Therefore, one of the most often applied (even if not explicitly named) methods in political science, in particular, in the areas of International Relations and European Integration (due to a relatively small number of cases which restricts the potentials of quantitative studies of comparative nature) is the so-called process-tracing ${ }^{16}$. According to Peter A. Hall, "process tracing has sometimes been denigrated as a simple injunction to study history, [although] it should be apparent that systematic process analysis [employed by political scientists] is <...> guided more extensively by theory than

\footnotetext{
${ }^{14}$ Susen, S. (2017), “No Exit from Brexit?" // Outhwaite W. (ed.), Brexit: Sociological Responses, London, New York: Anthem Press, p. 171-173.

${ }^{15}$ King, G., Keohane, R., Verba, S. (1994), Designing Social Inquiry: Scientific Inference in Qualitative Research, Princeton: Princeton University Press, p. 9.

${ }^{16}$ For more on this method see: Bennett, A. (2008), "Process Tracing: A Bayesian Perspective" // BoxSteffensmeier, J., Brady, H., Collier, D. (eds.), The Oxford Handbook of Political Methodology, New York: Oxford University Press, p. 702-721; Checkel J. (2008), "Process Tracing” // Klotz, A., Prakash, D. (eds.), Qualitative Methods in International Relations: A Pluralist Guide, Basingstoke: Palgrave Macmillan, p. 114-127; Panke D. (2012), "Process Tracing: Testing Multiple Hypotheses with a Small Number of Cases" // Radaelli, C., Exadaktylos, T. (eds.), Research Design in European Studies, Basingstoke: Palgrave Macmillan, p. 125-140.
} 
are most of [investigations] undertaken by historians"17. Nonetheless, despite of the ambition of political science to forecast the future, most of "theory-testing" work is conducted on the objects in the past.

Political forecasts and the planning based on them were applied among the analysts of politics back in the times of the Cold War, however, future studies properly entered the prevailing literature of political science (or rather came back) only in the $21^{\text {st }}$ century - specifically, the scenario building technique ${ }^{18}$. Advocates of this methodology consider forward reasoning and explanation "of the future" to be a legitimate way of a "scientific" study. As Steve Bernstein et al. put it, building of scenarios "is simply a form of process-tracing $<\ldots .>$ in future rather than past time"19. The main difference between the causal research of a process which has already taken place and designing a scenario is that a researcher does not seek to eliminate alternative explanants - or, in other words, independent variables, - and to identify the determinant reason; as long as the result stays in the future, all factors may be considered "determinant".

Methodological literature on scenario building defines scenarios as "descriptive narratives of plausible alternative projections of a specific part of the future. They are methodically researched and developed in sets of three, four, or more. $<\ldots . .>$ They are a combination of estimations of what might happen and assumptions about what could happen, but they are not forecasts of what will happen"20. Just like any other research method or technique, scenario building in practice is applied by complying with certain rules which allow other members of the academic community to replicate the research or at least "reconstruct" it. A methodologically proper set of scenarios usually includes the following components: 1) identification of driving forces, 2) definition of predetermined elements, 3) selection of values for the most important "unknown" elements, 4) arrangement of scenario plots in the form of a narrative, 5) naming of the early indicators in every of the scenarios ${ }^{21}$.

\footnotetext{
${ }^{17}$ Hall, P. A. (2003), "Aligning Ontology and Methodology in Comparative Research" // Mahoney, J., Rueschemeyer, D. (eds.), Comparative Historical Analysis in the Social Sciences, New York: Cambridge University Press, p. 395.

${ }^{18}$ See: Bernstein, S., Lebow, R. N., Stein, J. G., Weber, S. (2000), “God Gave Physics the Easy Problems: Adapting Social Science to an Unpredictable World", European Journal of International Relations, Vol. 6 (No. 1), p. 43-76; Neumann, I. B., Øverland, E. (2004), "International Relations and Policy Planning: The Method of Perspectivist Scenario Building", International Studies Perspectives, Vol. 5 (No. 3), p. 258-277.

${ }^{19}$ Bernstein et. al. (2000), op. cit., p. 55.

${ }^{20}$ Fahey, L., Randall, R. (1998) “What is Scenario Learning?" // Fahey, L., Randall, R. (eds.), Learning from the Future: Competitive Foresight Scenarios, New York: John Wiley \& Sons, p. 6-7.

${ }^{21}$ See: Fahey, Randall, op. cit., p. 10-12; Marsh, B. (1998), "Using Scenarios to Identify, Analyze and Manage Uncertainty" // Fahey, L., Randall, R. (eds.), Learning from the Future: Competitive Foresight Scenarios, New York: John Wiley \& Sons, p. 33-34; Weber, S. (1997), "Prediction and the Middle East Peace Process", Security Studies, Vol. 6 (No. 4), p. 171-174; Bernstein, S., Lebow, R. N., Stein, J. G., Weber, S. (2007), "Social Science as Case-Based Diagnostic" // Lebow, R. N., Lichbach, M. (eds.), Theory and Evidence in Comparative Politics and International Relations, Basingstoke: Palgrave Macmillan, p. 238-242.
} 
Driving forces of the scenarios are usually dictated by the theory as "explaining" or "independent" variables. Some supporters of the scenario building technique indicate environment (structure) and action (agency) level driving forces ${ }^{22}$; identification of the latter type of driving forces often demands knowledge of theory as well the context of a concrete case. Predetermined elements (or "constants") are the factors which clearly limit the development of analysed process within the chosen period of the scenario, and will most likely remain unchanged or will change following the clearly predictable trajectory; most often such predetermined elements are demographic trends or natural or climatic conditions which change considerably slower than political or social phenomena; they are described in scenario plots-lines. The most important critical uncertainties (or "variables") are both the strength and the weakness of the scenario building methodology at the same time. Their values are chosen by the researchers in a speculative manner and often absolutely arbitrarily, however, creative solutions of uncertainties lead to unexpected and often useful stories of the future. Alternative plot-lines of scenarios are, in principle, the most tangible "result" of application of this technique as they describe in detail the interaction of the most important driving forces under certain predetermined conditions and with certain values prescribed to critical uncertainties. Finally, the researcher names the early indicators, which are clearly measurable and will enable the observers to recognise which scenario is coming to live in the course of time. Early indicators are first needed in cases where scenarios are created for practical reasons and must help policy-makers adopt decisions but may also serve as a partial (although empirically poorly founded) instrument of theory testing.

\section{European Security Driving Forces from a Theoretical Viewpoint}

The issues of national, regional and international security in political science are usually raised by the scholars of International Relations who in the last six or seven decades have developed numerous theories which explain the different levels and behaviours in security area. They are usually categorised into "traditional objectivist" theories and post-positivist (or reflectivist) approaches

\footnotetext{
${ }^{22}$ E.g., Fahey, Randall, op. cit., p. 10.
} 
to the issue of security ${ }^{23}$. Reflectivist security studies are normally of historical nature and localise the sources of "security problems" in long-term discourses and long-term identities of human individuals and groups. By postulating constitutive (mutual constitution) relationship between action and structure these theoretical approaches do not actually single out any truly "independent" variables. Building future scenarios is more compatible with the objectivist paradigm in security studies, though it must be noted that ideational factors, which are usually found in the focus of reflectivist studies, inevitably affect security architecture of any region in the long term.

The oldest explanation of the post-war European security dynamics may be found in the realpolitik tradition - or in other words, in the literature of international relations which represents the theoretical tradition of realism. International behaviour of countries is explained by realists first and foremost through the strive for power and security in anarchical (self-help) international environment. The main modern-day European security structures - NATO, OSCE, also the predecessor of the EU - the EEC - were formed in the context of biploar competition among the superpowers during the Cold War (both in the continent and globally). After the end of the Cold War and the disappearance of the threat posed by the Soviet Union, realists forecast both the collapse of the transatlantic alliance between the Americans and the Europeans ${ }^{24}$ and the growth of confrontation among the European countries ${ }^{25}$. The continuation and development of NATO and other security cooperation institutions are explained by realists through the asymmetry of power within NATO and the pacifying military power of the USA which is directly manifested on the European continent even after the Cold War ${ }^{26}$. From a realist point of view, the unilateral actions by the USA, such as the 2003-2011 intervention in Iraq, and the clash of interests between the two sides of the Atlantic promote the development of independent EU military structures which are aimed at counterbalancing the power of the $\mathrm{USA}^{27}$. To put it differently, direct involvement of the US armed forces in the

\footnotetext{
${ }^{23}$ For example, see: Smith, S. (1999), "The Increasing Insecurity of Security Studies: Conceptualizing Security in the Last Twenty Years", Contemporary Security Studies, Vol. 20 (No. 3), p. 77-96; Miniotaite, G., Jakniūnaitè, D. (2001), "Lietuvos saugumo politika ir identitetas šiuolaikinių saugumo studijų požiūriu", Politologija, Nr. 3 (T. 23), p. 3-10. ("Lithuania's Security Policy and Identity from the Perspective of the Modern-day Security Studies").

${ }^{24}$ De Santis, H. (1991), “The Graying of NATO”, The Washington Quarterly, Vol. 14 (No. 4), p. 51-65.

${ }^{25}$ Mearsheimer, J. (1990), "Back to the Future: Instability in Europe after the Cold War", International Security, Vol. 15 (No. 1), p. 5-56.

${ }^{26}$ See: Walt, S. (1997), "Why Alliances Endure or Collapse”, Survival, Vol. 39 (No. 1), p. 156-179; Mearsheimer, J. (2001), "The Future of the American Pacifier", Foreign Affairs, Vol. 80 (No. 5), p. 46-61. ${ }^{27}$ Posen, B. (2006), "European Union Security and Defense Policy: Response to Unipolarity?", Security Studies, Vol. 15 (No. 2), p. 149-186.
} 
defence of the European continent, the strength of the transatlantic partnership and common threats of a continental scale are and will be among the key factors which will also determine the place of the UK in the future European security architecture.

Contrary to the realist tradition, in the tradition of neoliberal institutionalism (which includes the studies of international regimes), the focus is put on the reasons of international cooperation, not on competition and rivalry over power. Although international institutions in the anarchical international environment actually provide the countries with information on each other and thus reduce cooperation costs incurred from distrust in partners (opponents), as one of the originators of neoliberalism in the international relations Robert Keohane put it, "without a basis either of hegemonic dominance or common interests, international institutions cannot long survive"28. Neoliberal models, like those of realists, are based on the assumption of a rational actor. Lisa L. Martin states that under the conditions of asymmetry, it is always cheaper and less risky for a stronger actor to institutionalise international negotiations instead of continuously wasting resources on countering resistance ${ }^{29}$. While the European countries established and developed supra-national EU institutions - in particular, after the Cold War and the collapse of the Berlin Wall - the united Germany became a benevolent hegemon, which agreed to fund the creation and maintenance of common market institutions and an economic and monetary union $^{30}$. Informal leadership of Berlin in the EU and synchronisation of the Germany and France's duo is therefore included among the main driving forces shaping the European security architecture after Great Britain's withdrawal from the EU.

Finally, the innenpolitik theoretical tradition in international relations specifically, the two-level game theory - derives the results of any international negotiations from the political competition within the states and the strategy of "victory on both fronts" (domestic and international) which is pursued by the political elite of any individual country. The key aim of the governing politicians is to remain in power, and the implementation of this goal depends on the support of the country's society and interest groups. Differently from what

\footnotetext{
${ }^{28}$ Keohane, R. (1993), "Institutional Theory and the Realist Challenge after the Cold War" // Baldwin, D. (ed.), Neorealism and Neoliberalism: The Contemporary Debate, New York: Columbia University Press, p. 295.

${ }^{29}$ Martin, L. L. (1992), “Interests, Power, and Multilateralism”, International Organization, Vol. 46 (No. 4), p. 784 .

${ }^{30}$ For example, see: Crawford, B. (2007), Power and German Foreign Policy: Embedded Hegemony in Europe, Basingstoke: Palgrave Macmillan; Bulmer, S. (2014), "Germany and the Eurozone Crisis: Between Hegemony and Domestic Politics", West European Politics, Vol. 37 (No. 6), p. 1244-1263.
} 
realists or neoliberals-institutionalists state, the "national interest" which is defended by the government in international negotiations, is not objectively fixed and is composed of the interests of such number of subnational actors which can ensure the survival of governments. Robert Putnam calls this a win-set ${ }^{31}$. Besides, theorists of two-level negotiations claim that governments are not merely the "gatekeeper" of interests emanating from the society on the international level but actively manipulate domestic and foreign actors in implementing their own agendas ${ }^{32}$. Previous research in political science provides solid empirical evidence of how re-allocation of power in the governing elite and corporate links between the state and business impact the most important of national foreign and security policies, for example, armament, policy of alliances or resolution of regional conflicts ${ }^{33}$. For this reason, stability of the UK's government and the society's support to it shall also be included among the driving forces in this scenario building exercise ${ }^{34}$.

To summarise the main assumptions of all the listed theoretical paradigms, four driving forces may be singled out which will form the basis for the scenarios provided in the third part of this article, namely: 1) USA's involvement in the European security architecture, 2) existence of threats of a regional scale, 3) leadership of Germany and France in promoting the European security (and other type of) integration, 4) stability of Great Britain's government and its political agenda. The critical uncertainties would be the scope and content (quality and quantity) of these driving forces, for instance, enthusiasm of Germany and France while promoting the EU integration may not only increase or decrease but also occur in different areas, among which integration in the field of defence is only one of many possibilities; the British conservatives may retain the control over government but in the context of falling approval ratings,

\footnotetext{
${ }^{31}$ Putnam, R. (1988), "Diplomacy and Domestic Politics: The Logic of Two-Level Games", International Organization, Vol. 42 (No. 3), p. 437.

${ }^{32}$ Putnam, op. cit., p. 456-459; Moravcsik, A. (1993), "Integrating International and Domestic Theories of International Bargaining" // Putnam, R., Evans, P., Jacobson, H. (eds.), Double-Edged Diplomacy: International Bargaining and Domestic Politics, Berkeley: University of California Press, p. 30-31.

${ }^{33}$ For example, see: Lantis, J. S., Kaarbo, J. (2003), “The 'Greening' of German Foreign Policy in the Iraq Case: Conditions of Junior Party Influence in Governing Coalitions", Acta Politica, Vol. 38 (No. 3), p. 201-230; Trumbore, P. (1998), "Public Opinion as a Domestic Constraint in International Negotiations: Two-Level Games in the Anglo-Irish Peace Process", International Studies Quarterly, Vol. 42 (No. 3), p. 545-565; Moravcsik, A. (1993), "Armaments among Allies: European Weapons Collaboration 1975-1985" // Putnam, R., Evans, P., Jacobson, H. (eds.), Double-Edged Diplomacy: International Bargaining and Domestic Politics, Berkeley: University of California Press, p. 128-167.

${ }^{34} \mathrm{By}$ analogy, the foreign and security policy of other major European / NATO countries is influenced by their internal political competition and the stability of their governments, but the position of the British government influences the Brexit process itself, i.e., it can pause Brexit or even revoke it; domestic changes in the U.S., Russian, or German politics (as much as they bear influence on their foreign policy) fall under the first three driving forces.
} 
an election campaign or a parliamentary negotiation over the support by small political parties may promise the voters and partners in power concessions so great that they would disturb the traditional pro-Atlantic and euro-sceptical stance of this party on foreign policy issues.

The predetermined elements chosen for the below provided scenarios include the national military manpower since even relatively radical military reforms (for instance, introduction of universal conscription) in peacetime increases the number of military staff only gradually; thus a steep jump in the human resources of the armed forces is hardly likely in the discussed period. It is likely that the most numerous armed forces in the region for the next few years will remain the USA $(\sim 1.37$ million of active military staff $+\sim 1$ million of active reserve), Russia ( $\sim 0.8$ million $+\sim 2.57$ million, accordingly), Turkey $(\sim 0.38$ million $+\sim 0.36$ million), France $(\sim 0.2$ million $+\sim 0.18$ million), Italy $(\sim 0.25$ million $+\sim 0.02$ million) and Germany ( $\sim 0.18$ million $+\sim 0.03$ million). In 2017, the UK had only $\sim 0.15$ million of military personnel $(+\sim 0.08$ million in reserve) and ranked below such European countries as Ukraine or Greece ${ }^{35}$. But in 2017, the UK had the highest defence budget (USD 46 billion) among all European countries (including Russia) ${ }^{36}$. As the defence budgets of countries are limited by the overall capacity of the national economy, the approximate indicator of the countries' GDP shall also be considered a predetermined element: in terms of the nominal GDP, the USA (the GDP of which in 2017 amounted to USD 19.36 trillion; by the year 2022, according to the forecasts of the IMF, it should reach USD 23.5 trillion), Germany (USD 3.65 trillion in 2017 and USD $\sim 4.5$ trillion in 2022, accordingly), France and the UK (in 2017, both - USD 2.57 trillion, and USD 3 trillion in 2022) ${ }^{37}$ should be considered the key "players" in the region, meanwhile, Russia and Turkey (their GDP amounted to USD 1.47 and 0.84 trillion in 2017, accordingly, and in 2022, potentially - USD 1.8 and 1.1 trillion, accordingly) can hardly challenge the USA and the EU Member States economy-wise, and therefore it would be difficult for them to increase military or border control capabilities dramatically. Regardless a few separatist movements and a few (in terms of power balance, relatively insignificant) territorial conflicts in the European continent, the modern-day territorial status $q u o$ is also considered a predetermined element.

\footnotetext{
${ }^{35}$ Total Available Active Military Manpower and Total Available Reserve Military Components by Country, Data through 2017. Available at: https://www.globalfirepower.com [accessed on 30-01-2018].

${ }^{36}$ Defense Spending by Country, Data through 2017. Available at: https://www.globalfirepower.com accessed on 30-01-2018].

${ }^{37}$ GDP, Current Prices. IMF DataMapper. Available at: http://www.imf.org/external/datamapper/datasets/ WEO [accessed on 30-01-2018].
} 


\section{Scenarios of Evolution of Regional Security in Europe after the Withdrawal of the UK from the EU}

\subsection{Scenario A: Closer European Security and Defence Union}

With a country having the biggest defense budget withdrawing from the EU, the USA starts questioning the EU's capability and effectiveness to be the main partner in solving global security problems. For a smoother resolution of security problems in East Asia (e.g., nuclear threat posed by North Korea) and the Middle East, the USA turns to Russia and, in principle, chooses the pragmatic path of "reconciliation". Although on diplomatic level Washington still claims to support re-integration of the territories of Ukraine and Georgia, de facto, Crimea is "sacrificed" in exchange for reduced support to separatists in Donbass and suspension of arms race. Russia withdraws part of its weaponry from the Kaliningrad Oblast and western regions of the country, meanwhile, Americans gradually reduce the number of rotational forces in Europe (especially, Eastern) and joint exercises with NATO allies. Besides, with every new administration the USA increasingly criticizes European countries for spending too little on defence, and for assuming too small share of responsibility for the security situation in the world (EU, just like the USA, commands $1 / 4$ to $1 / 5$ of the global wealth) and refuses to support European interventions in Africa and other regions of the world by providing its armed capabilities.

Although after the nominal "restart" of relations between Russia and NATO any direct military threat to certain European countries decreases, civil conflicts and regimes supporting terrorism in Africa and the Middle East remain a relevant security problem (in fact, they become even more important issues) on the European agenda. With the shrinking military support of the USA, Germany and France reach the principal agreement on the creation of a genuinely effective European security and defence union which would be funded from the European budget and where the critical European security issues would be discussed (in most cases, this format is given priority over the North Atlantic Council). The tasks listed in Article 43 of the Treaty on European Union and delegated to the EU missions and EU Battlegroups are expanded by potentially including air force capabilities and by attributing the functions of "air policing" or enforcing "no-flight zones" to EU missions. Although the attribution of the functions of collective defence to the European security and defence union in the framework of the EU is seriously discussed in public, a closer European defence integration 
for the time being is mostly associated with security challenges rising beyond the borders of the continent. Still, based on this scenario, the significance of NATO as of a security body decreases and the role which was taken on by this organisation after the Cold War is partially taken over by the EU.

Having unsuccessfully attempted to become the "bridge" between the both sides of the Atlantic, the UK, which is still ruled by the Tory government, (and having one of the biggest defence budgets in Europe), shows leadership in creating a closer European security and defence union. Although following this scenario, the big EU countries - Germany, France, Italy - considerably increase their defence spending, participation of the UK in the creation of the European security architecture independent from the USA is still necessary, in particular, with the aim to ensure the effectiveness of European expeditionary missions. In exchange for participation in the new European security and defence Union the UK is offered exclusive conditions (a type of "preferential" deal) in the economic relations with the EU after its withdrawal (in principle, free trade in goods and services on the single EU market, a certain vote when adopting the future decisions of the union, and the actual "brake" for free movement of people from the EU, e.g., selective employment regime for occupying vacancies in the UK's labour market). The British society demonstrates a clear approval of the "pro-European" conservative policy, and the format of relationship with the EU beneficial for the country (in principle, by putting into action the will expressed by the citizens in the Brexit referendum and at the same time preserving the advantages of membership in the EU) which guarantees re-election of the Tory party in 2022 .

\subsection{Scenario B: \\ a New "Cold War" in Europe}

In response to the withdrawal of one of the historically fiercest Russia's opponents ${ }^{38}$ from the EU and the growing disagreements within NATO and the EU (e.g., increasingly divergent standpoint of Turkey, Hungary or Poland), Russia increases military pressure and diplomatic influence in Europe. As a protest against the accession of Sweden and Finland to the Alliance (which is publicly discussed in NATO summits), Moscow unilaterally terminates NATO-Russia Council meetings, cancels delegations of its parliament members to Council of

\footnotetext{
${ }^{38}$ See: Campbell, H. A. (2019), "One Hundred Years on: The Russian Revolution and Anglo-Russian Relations Today", Global Affairs, Vol. 5 (No. 1), p. 41-53.
} 
Europe and OSCE Parliamentary Assemblies, increases its military presence in Belarus, Armenia and the Crimean Peninsula and adopts a new national security doctrine in which its main and vital interest is stopping the "American imperialism". In return, Washington doubles its forces and the scope of joint exercises of the Alliance at the eastern border of NATO and starts publicly discussing the possibility of deployment of a nuclear weapon to Poland. The big countries of the European continent (Germany, France and Italy) join the American efforts on the eastern NATO "flank", however, they still avoid increasing national capabilities. Given the growing military confrontation in Europe, NATO remains the most important and relevant security organisation as it was after the Cold War.

At the same time, the UK is "trapped" in the transitional period (2-5 years, with the possibility of extension for 5 more years) between the membership in the $\mathrm{EU}$ and absolute sovereignty. It continues participating in the single EU market of goods, services, capital and labour and applies the acquis of the Community in its domestic law system; however, after the end of the deadline of two years given for withdrawal from the EU as stipulated in Article 50 of the Treaty on European Union (from April 2019), it loses its voice in making legal decisions in any form. Such situation weakens the popularity of the British conservative party and forces its Prime Minister Boris Johnson to organise another premature election. During the election campaign, the opposition Labour party and liberal democrats promise a second referendum on UK's membership in the EU. Taking into consideration the complicated international situation, Germany and France, which at the beginning of the so-called Brexit negotiations in 2017 sought to punish the arogant Brits, unexpectedly approve the initiative of the European Commission with regard to the simplified procedure of returning UK to the Union; the possibility for the UK to return to the EU is also publicly supported by the USA. In fact, with the popularity of the opposition growing, Jeremy Corbyn ${ }^{39}$, the Labour leader who becames the front-runner in the early election, also promises his electorate to destroy the British nuclear arsenal, reduce defence spending (giving priority to the welfare programmes) and refrain from any new war, thus notably weakening the general standpoint of the West with regard to Russia.

\footnotetext{
${ }^{39}$ For more on Jeremy Corbyn's foreign policy agenda see: “The Pacifist Illusion: Jeremy Corbyn's Reluctance to Use Force Threatens to Make the World a More Dangerous Place”, The Economist, 21st-27th April, 2008, p. 51.
} 


\subsection{Scenario C: Multipolar World and Revival of "Anglosphere"}

Taking advantage of withdrawal from the EU, the British conservative government indicates that "reloading" of the "special relationship" with the USA is their main foreign policy priority and puts forward the ambitious neo-imperial idea of the global "Anglosphere" ${ }^{40}$ As the success of the latter strategy directly depends on the diplomatic support from the USA, London first tries to build the new partnership with Washington on strong economic relations which would compensate its withdrawal from the EU single market. The British informally conduct negotiation with the Americans over the possible free trade zone even though the so-called Brexit negotiation has not been finalised yet; the first protocols establishing such zone are to be signed in the next three or four years. By the end of this scenario span, the UK has entered into analogous negotiation over free trade agreements with Canada, Australia and, potentially, India. Although the "Anglosphere" is not turning into any formal international organisation, having used all diplomatic resources London "obtains" important political declarations of Washington, New Delhi or Tokyo on a unified position on critical international security issues, such as international terrorism and arms control. In other words, based on this scenario, the world is moving towards a multipolar international system which has a few more or less equivalent power centres from the political and economic (but not military) point of view; in this scenario, multilateral solution of security problems is preferred to confrontation. Such situation is beneficial to the UK which is capable of manoeuvring among the partners and in this way gains a certain (somewhat bigger than being an EU member) international role and secures the popularity of conservatives within the country.

In this scenario, the EU is one of the such centres of power which - having dropped the "British anchor" and driven by the Berlin-Paris double engine - takes up some new ambitious integration projects. In fact, differently from what scenario A provides for, these projects first include the areas of social and economic policy and cooperation in the field of justice and home affairs (e.g., more effective external border control by assigning more powers to the supranational agency FRONTEX, coordination of social benefits to non-EU citizens or harmonisation of taxes in the single market). Still, the EU does not become the priority inter-governmental forum of a continental scale in the security area. The independent UK wins over most "pro-

\footnotetext{
${ }^{40}$ For more on the historical development of the idea of "Anglosphere" see: Wellings, B., Baxendale, H. (2015), "Euroscepticism and the Anglosphere: Traditions and Dilemmas in Contemporary English Nationalism”, Journal of Common Market Studies, Vol. 53 (No. 1), p. 123-139.
} 
Atlantic" EU Member States (first of all, Eastern European countries, Ireland, maybe Denmark) and Turkey, and seeks to elevate the new threats of the $21^{\text {st }}$ century, such as cyber-attacks or terrorism, to the agenda of such organisations as OSCE which, in terms of membership, are considerably more inclusive than the EU.

Table 1. Combinations of Driving Forces in the Scenarios of Evolution of the Regional European Security Architecture after Brexit

\begin{tabular}{|c|c|c|c|c|c|c|c|c|c|}
\hline & & \multicolumn{8}{|c|}{ Driving forces } \\
\hline & & \multicolumn{2}{|c|}{$\begin{array}{l}\text { Involvement } \\
\text { of the USA in } \\
\text { Europe }\end{array}$} & \multicolumn{2}{|c|}{$\begin{array}{l}\text { Threat of regional } \\
\text { scope }\end{array}$} & \multicolumn{2}{|c|}{$\begin{array}{l}\text { Leadership } \\
\text { of Germany } \\
\text { (+France) }\end{array}$} & \multicolumn{2}{|c|}{$\begin{array}{l}\text { Government of the } \\
\text { United Kingdom }\end{array}$} \\
\hline & & strong & weak & $\begin{array}{l}\text { clearly } \\
\text { visible }\end{array}$ & $\begin{array}{c}\text { abstract } \\
\text { (vague) }\end{array}$ & strong & weak & stable & weak \\
\hline \multirow{3}{*}{ 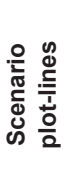 } & Scenario A & & $x$ & \multicolumn{2}{|c|}{$\sim$} & $x$ & & $x$ & \\
\hline & Scenario B & $x$ & & $x$ & & & $x$ & & $x$ \\
\hline & Scenario C & $x$ & & & $x$ & $x$ & & $x$ & \\
\hline
\end{tabular}

\section{Conclusions: Evaluation of Scenarios}

Scenarios listed in this article - just like the scenario building methodology itself - cannot help predict the future since a storyline construed by political scientists rarely materializes in full. As noted by one of the advocates of this method in political science Steve Weber, "scenarios are effective if they open people's minds to possibilities that they did not previously consider, so that their level of surprise on encountering the future is reduced" ${ }^{21}$. All three plot-lines of this scenario-set include an element of "brain-storming" and may be useful when adopting a decision on political or bureaucratic level. Still, from the scientific point of view, they neither strongly support, nor completely disprove any of the theories used in designing them. The set of scenarios depicted in this article only shows the extent of influence of the variables derived from respective social and political theories on the regional security architecture analysed herein. In terms of the orthodoxy of political science, scenario building should most probably be identified with the tradition of "theoretical eclecticism" which is increasingly advocated by some political scientists ${ }^{42}$.

\footnotetext{
${ }^{41}$ Weber, S. (1996), “Counterfactuals, Past and Future” // Tetlock, P., Belkin, A. (eds.), Counterfactual Thought Experiments in World Politics, Princeton: Princeton University Press, p. 287.

${ }^{42}$ For example, see: Katzenstein, P., Sil, R. (2010), Beyond Paradigms: Analytic Eclecticism in the Study of World Politics, Basingstoke: Palgrave Macmillan.
} 
It is difficult to unambiguously name the early indicators of each of the provided scenario plots, since both the European security and defence union and the "Cold War" of a regional scale, as well as the global "Anglosphere" may materialise (or move towards materialisation) in different ways. Yet, it is evident, that public declarations of the "big EU troika" - Germany, France and the UK - or (more importantly) contractual obligations with clear deadlines for creating a supranational defence funding, open (i.e., involving non-EU states) European high readiness armed forces, etc. would signal the materialisation of scenario A. More frequent meetings of the heads of the English-speaking countries - in particular, if during them the emphasis was put on the importance of the common "Anglo-Saxon heritage" - would give grounds to expect that scenario $\mathrm{C}$ would come to reality. Meanwhile, the quantitatively more frequent references to the "Russian threat" by an increasing number of European leaders (including leaders of non-NATO states) in reference to the subversive Russian activities vis-à-vis the EU and NATO Member States, would be the first sign of the emerging "cold war" (scenario B). Still, as the previous experience of applying the scenario building technique shows, in the medium term, materialisation of only of some of the aspects of the three scenarios is most likely and they would most probably occur at the same time.

None of the scenarios provided above could be boldly named as "favourable" or "unfavourable" to Lithuania. Scenario B would mean the general growth of conflictual relations across the region, including the nuclear confrontation between NATO and Russia, in which the likelihood of a mistake and its price would be the highest. In fact, in this case the focus of the USA on the Central and East European (CEE) region and the Baltic countries would also be most evident. Although scenario A would come about as a relative decrease of tension in the NATO-Russian relationship, it could be interpreted as NATO's "defeat" in an undeclared "cold war", which, in principle, has been taking place since 2014. If the USA and Russia manage to reach a consensus of one or another kind with regard to the "spheres of influence" in Europe, the small countries, in particular, those which are on the periphery of such spheres, would face a real threat to be sacrificed on the "altar of reconciliation". Recognition of the sphere of influence of Russia on the part of the USA / NATO would amount to failure of the long-standing goal in Lithuanian foreign policy to integrate such countries as Ukraine and Georgia in the Western structures. Finally, scenario C would most likely leave Lithuania overboard the "quasi-federal" core of the EU, unless it agreed to 
give up more of its sovereignty to the supranational centre of power. On the other hand, having identified long-term global and regional trends - not least with the help of this scenario building exercises - Lithuania may also discover some new opportunities and maybe even adjust the direction of its foreign and security policy, which, in principle has been stable since the restoration of its independence.

July 2018 